\title{
千篍県茂原ガス田纪於けるガムマ 線探鉱法による潜在斷層の探查
}

\section{浯田隆 阴*}

（昭和27年 1 月11日受理）

\begin{abstract}
Exploration of Buried Faults at the Mobara Natural
Gas Field, Chiba Pref. by means of Gamma Ray Method.
\end{abstract}

\section{by Takato Fuchida}

The author observed the positi e correlation between the maximum of the surface gamma ray intensity distribution and the known fauIt in his preliminary tests, the result of which has been already published.

In the present work, he shows the gamma ray intensity distributions (Fig 2(A) \& (B)) in the virgin area (Fig 1 (A) \& (B)) of the Mobara Natural Gas Field. Some of the maxima of the intensity curves seem to show fairly the possibilities of buried faults.

\section{1. 緒言}

筆者は，昭和25年，同26年の夏，それぞれ約 1 万月にわたり，大多吉天然

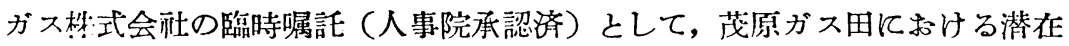

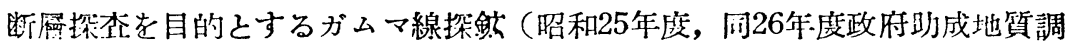
杢）をおこたつた。同会社の御諒解を得てここにその䋹果を簡単に発表す る。

\section{2. 目 的}

断層に件う破所帶の存在は，もしそれが適切をる深度にあるように探掘井

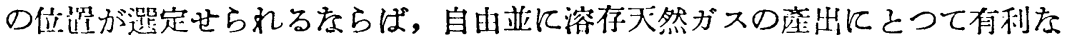

* 東京大学工学部敉授 
条件を加万るものであることは, 容易に推理せられるところであり, 実際に 茂原ガス田における過去の実績において認められている。

そらいうわけで，まだ本格的に䦎発されたい茂原町の北東方の冲積本地に

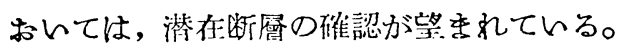

この調杢恃, 地表におけるガムマ線蝐度が, 潜在断層の直上部において極 大值を示す場合があるという事実を根拠 ${ }^{* 1)}$ として, 上記地区の潜在断尿推 定の 1 資料たらしむべく，地表におけるガム、線强度の分布狀態を調べよう とするものである。

\section{3. 测定}

両年度にわたり，篗者が使用したガム、線品度测定裝邆は, 野外携帶用之 して便利たように，篗者の実験室において組立てたものであり，経験ととも

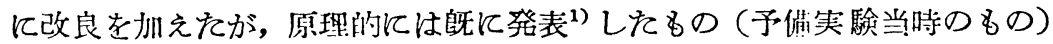
己変ら壳いのでここに詳說することは省略する。そして以下においては， 探䥄上特飞留意した测定上の注:意 $2 ， 3$ を記しおくによどめる。

ガムマ線感知部たる G. M. 計数管（直径 $5 \mathrm{~cm}$, 辰さ約 $4 . \mathrm{cm}$ ) は, 地表上

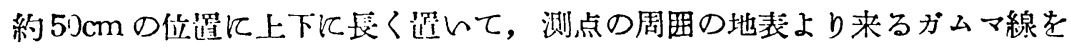
本均的によく受けいれられるよう留意した。

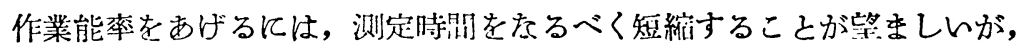
それは测定优の精法の低下を来たす不都合があるので，総合的兄知より测定 時間10分として終始した。その場合の测定値の相対碓率部差は, 理論的には もちろんであるが，实験的にも2\%以下にとどまることを倠めてある。

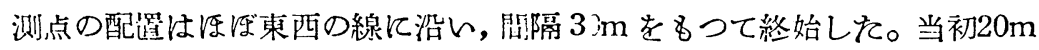
をるつて始めたが，测定されたガムマ線强度の变化の狀態より推して，その 程度が変化の実態志一応上く把え，しかも能率をあげるに適当であろうと考

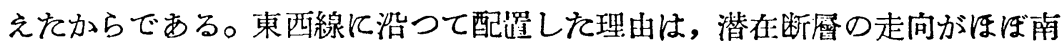
北であると，推定されているからである。

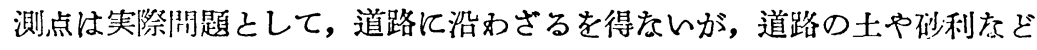
は他の土地より運んだものかも知れず，しかもそれが比较的罢い放射能でも 持つている場合には，本来の测定の意味を失うことになるので，か〉る虞れ がもしあるにしてる，なるへくとれを避けたい意味において，でをるだけ道

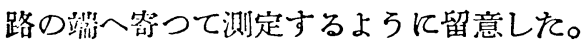

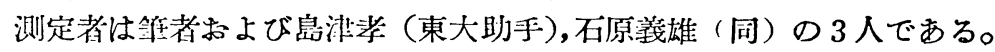

* 筆者がガム、線强度測定孛，上迅の如き目的红利用しよろと試みたのは，従来の放 射能探鈯の1つで女つたラドン法に代り,より有效にして能率的なすのと考えて, 昭

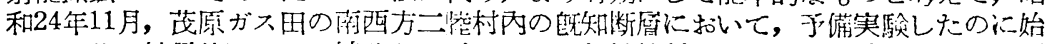
なる。その結果亚にガんマ線法とラドン法との比較検討についての当時の筆者の見解 などは，文献 1) を参照せられたい。 


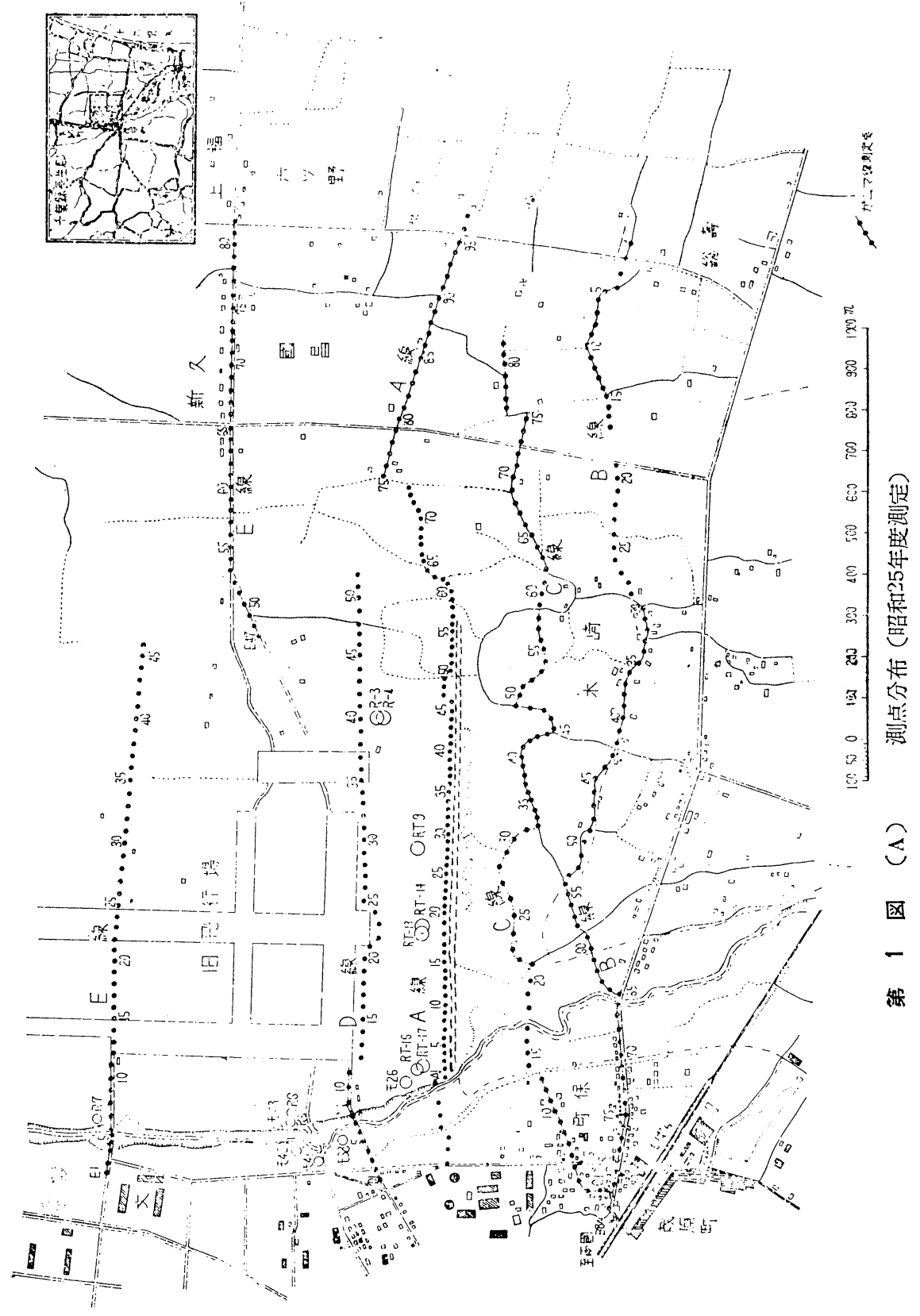




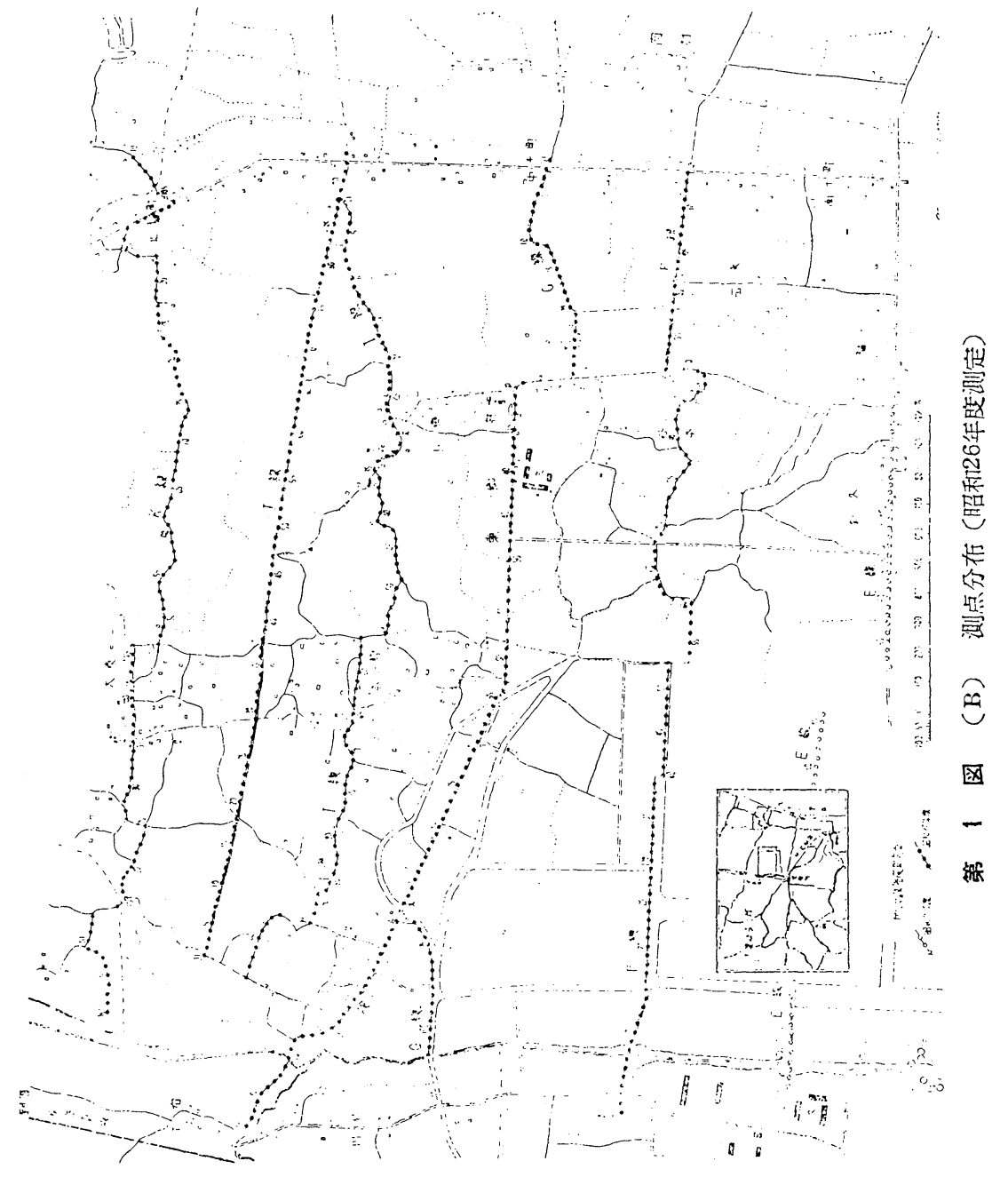

\section{4. 測 定 結 果}

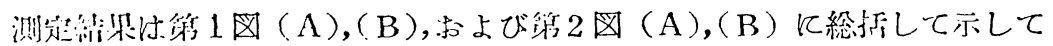
可分。

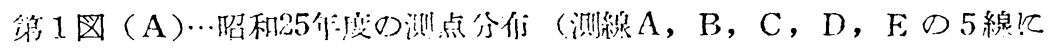
則れている)

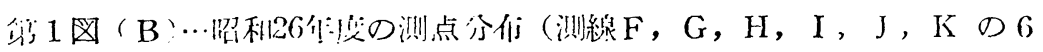



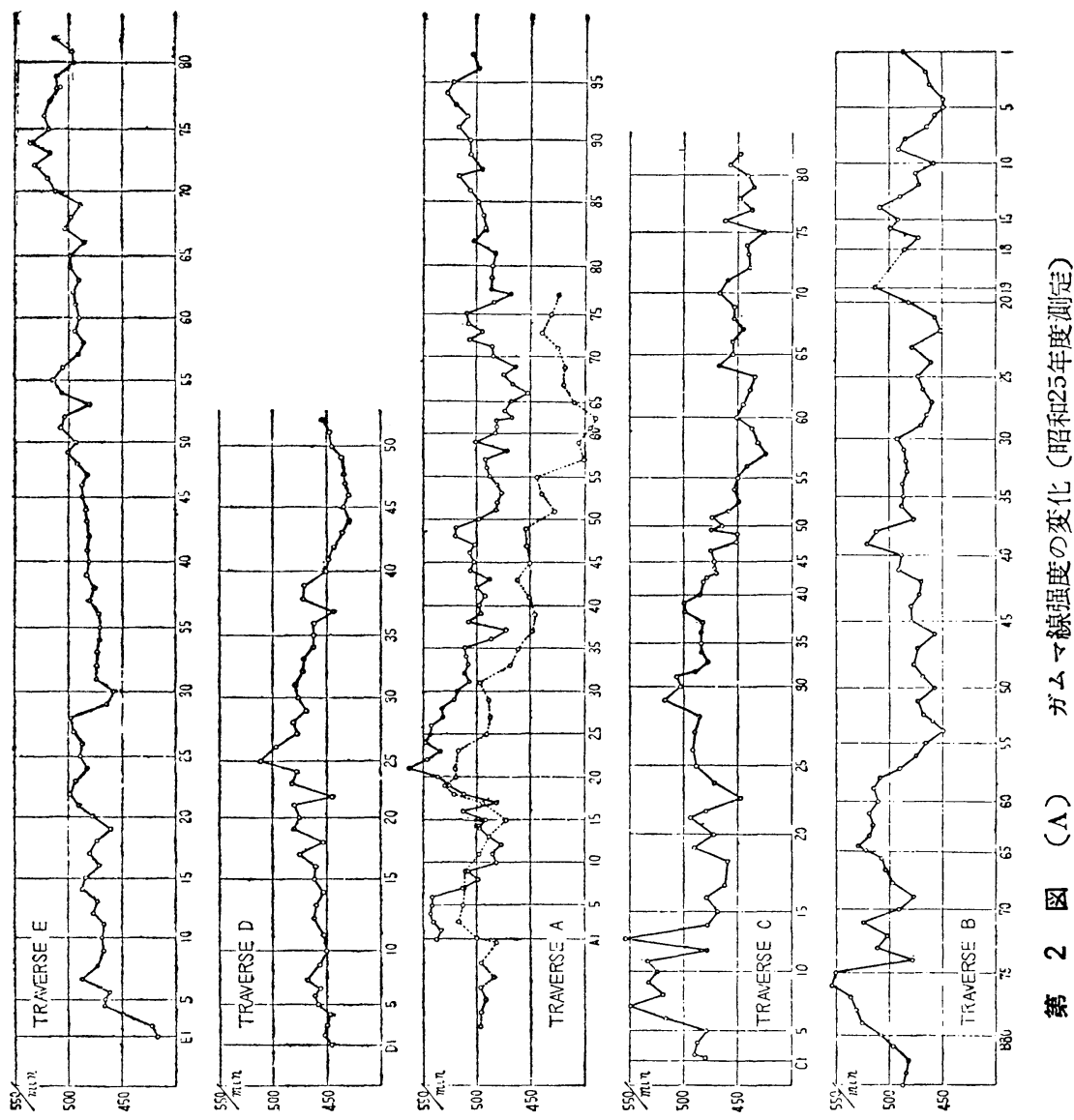

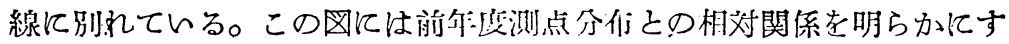
るために，E線の1部老も示してある）

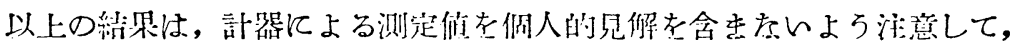

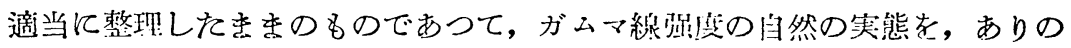
ま〉示するのと走すべものである。以下においては, 参将のため, 今回

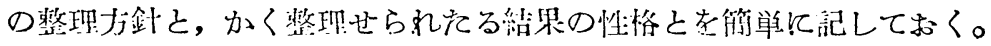

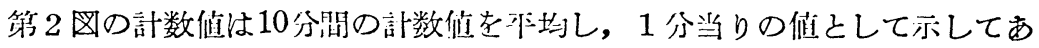
る。

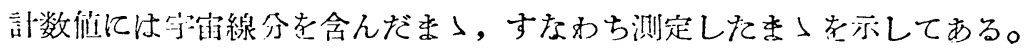

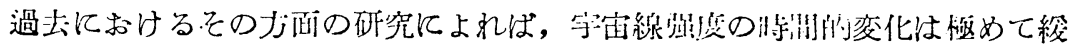



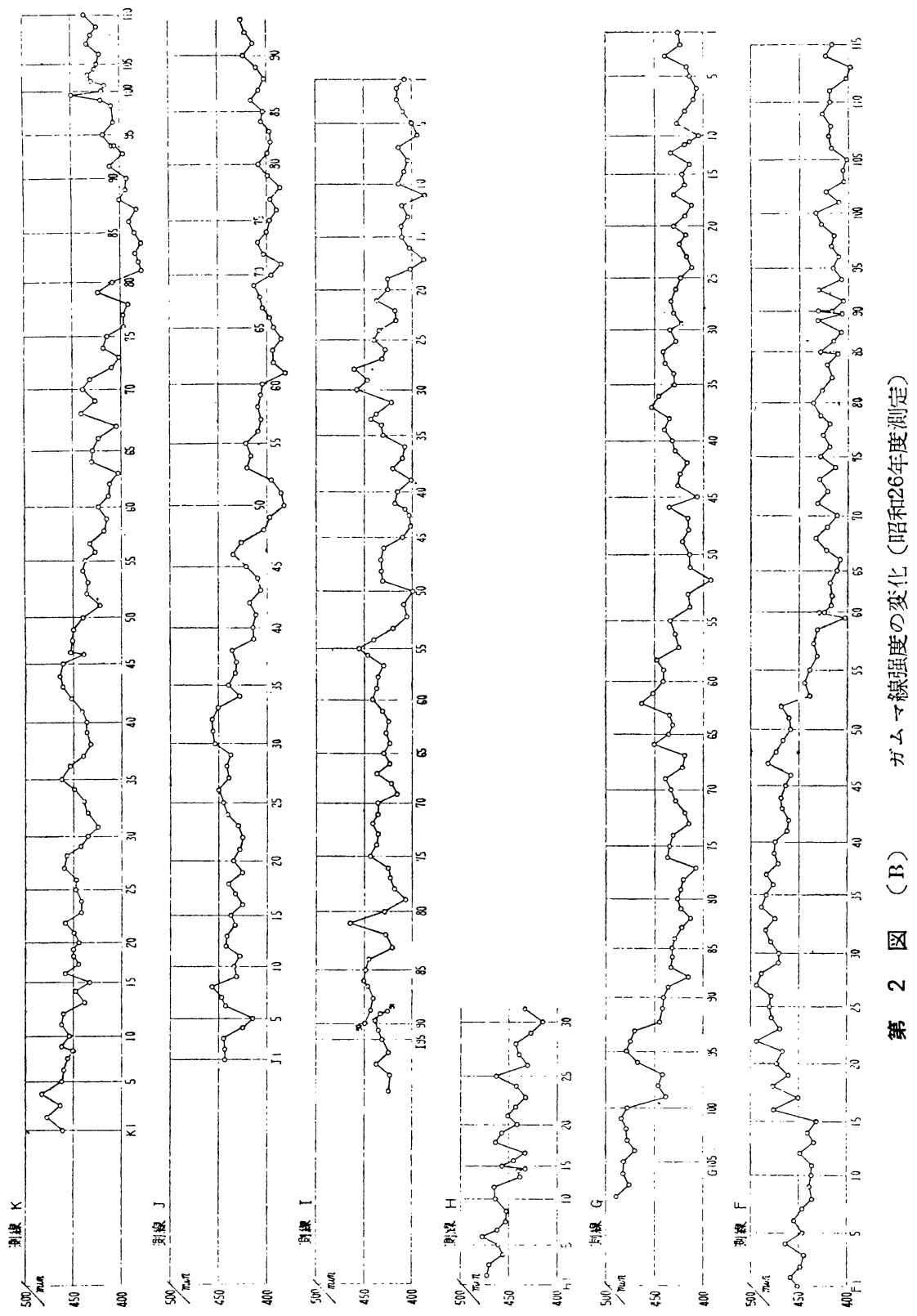


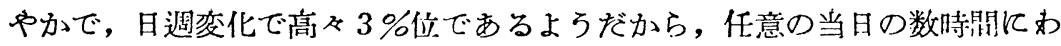

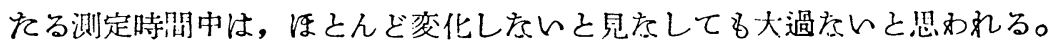

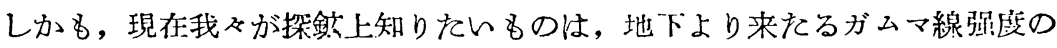

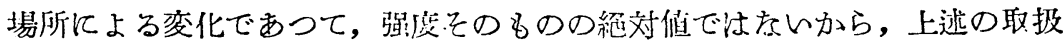
いでさしつかえはない。(純楼:の宙線分を知るには，たとえば九十九里浜沖 合の海上にでも出て，地下からのガムマ線のたい所で等宙線佋臤を計量しな ければならないので, 非常に面倒であり，しかも必柇も必要でないこと上 䢑の如くであるので, やめたわけである。）

計数值恃各测線每に，第 1 测点（A 1，B 1 の如し）を测定した当日の爿 態に補正し，その测線に沿つを变化狀態はとのま〉曲線をみればわかるよう

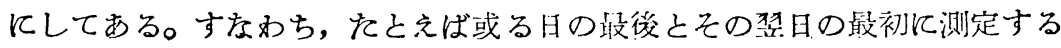
共通点の值は，一般にピタリ之は一致したいのであるが，それは計数俌の中 に含まれる宇宙線分の変化に基くものと見夵して, 整理したわけである。こ れは，よしんば正しくはそうでをくても，商ヶ3\%以下位の喰迨いであるの で,上述の取扱により藷しく自然の笑態が柔められることはないと思われる。

第 2 因 (A) と（B）のそれでれの平均計数值は，使用したG. M. 計数管 が買るため, 後者が約 1 割位少た目に出ている。したがつて, 変化の姿態老 兄るにはそのをつでよいが，変動量そのものは，兴者のおがそれだけ少な目 に現われていると見ておくべきであろう。

解 2 因 (A) のA测線汇示してある点線の曲線は，大雨が 2,3 日続いた 後で再测した結果である。裴土への浸透水や低地の溜り水のために，地下か らのガムマ線が乎分吸收されて，計数値の絕対佔红減少しているが，場所て よる变化の资態が両者よく非徃を示しているのは，ガムマ線强臤の場所飞 よる变化の実態が，比校的よく把握されていることを物語つている*。

\section{5. 測定結果の解釈について}

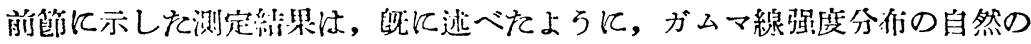

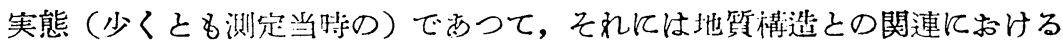

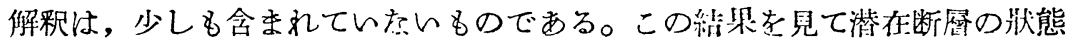

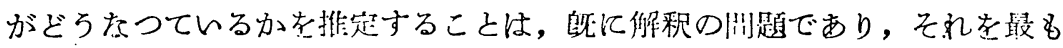
確からしいるのにするには，この資料のみ衣らず，他の，少くとも断展閌題

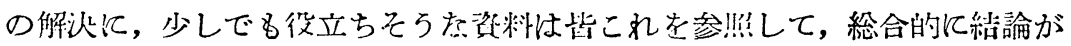
引き出されるべきである。

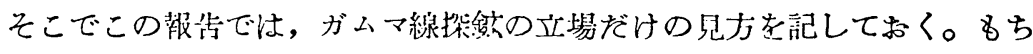

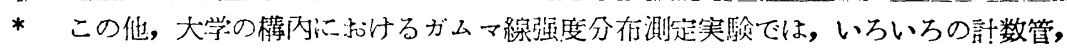
日時などに関しても試殹しているが，一樣汇平䘕性を示すことがかかつている。 


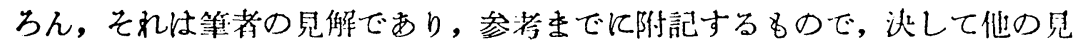
方をすべて否定するつもりはをい。

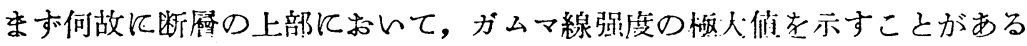

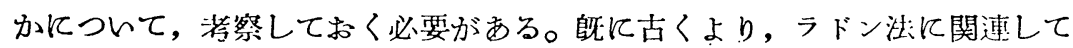

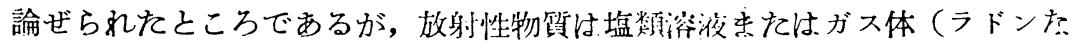

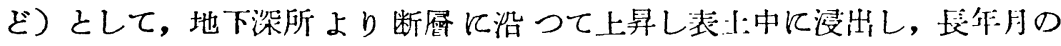
開飞集積しているのであらら。そして放射性現象の知識より推察して,ラト

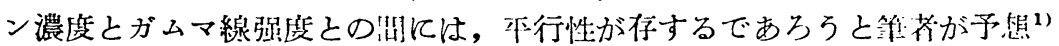

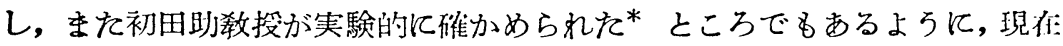

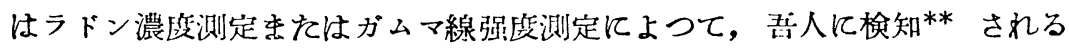
程度に友つているのであろう。

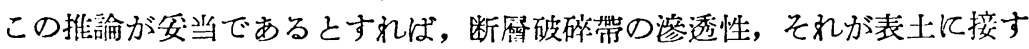

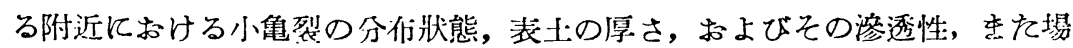

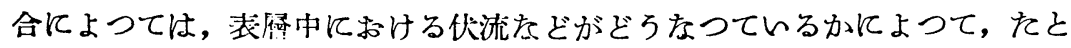

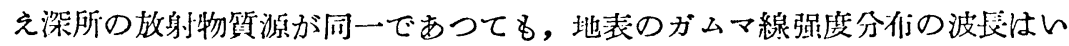
ろいろの形飞なるであろう。しかしとにかく，その值が大をくなる所は，一 応断瓷潜在の可能性がある胃てさしつかえ恃をいはボである。したがうて 第 2 因について解积をするには，ま亦曲線の極大部に着目するのが順序とな り，しかるをれが唯一の根抛と空るよう思われる。

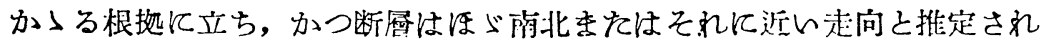

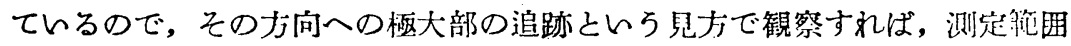

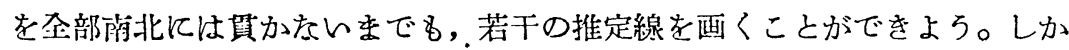

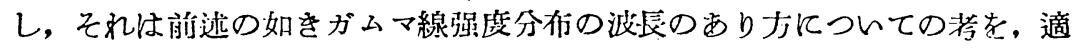

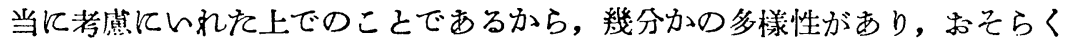

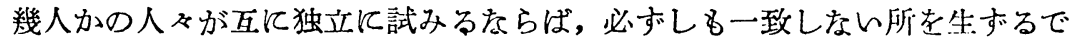

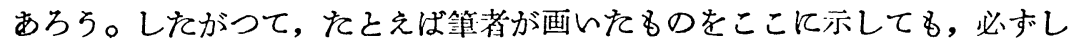

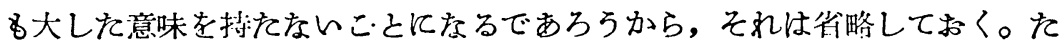

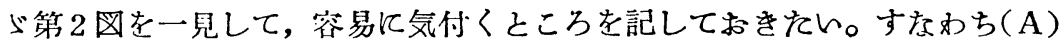

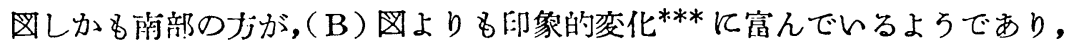
両地区の諸条件の䦌飞何らかの相賞を思わしめるものがある。これについて

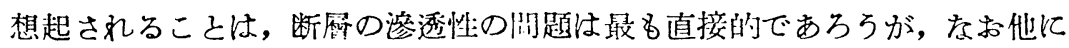

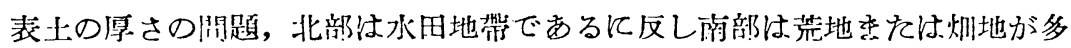
いなどのこと，その他である。こ礼らが具体的に如何飞絬果と関連している

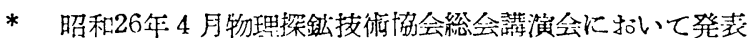

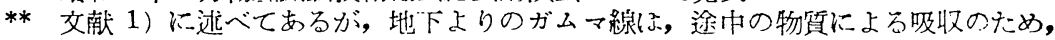

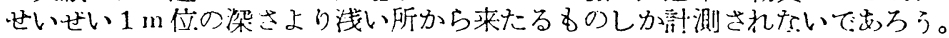

***この地区の四，中，東部の変化は，既に他の資料より推定せられている断厤とよく 対伈していること才゙認められる。 
かは，現在においては断定のしようのをいことであるように思われるが，願

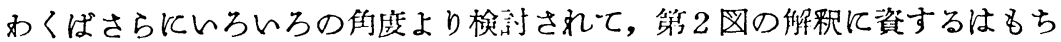
ろん，さらに將来への碟石となるようにしたいものではある。

掫後に附㞦えておきたしとは，当地の天゙然ガスの放射能についてである。 昭和25年には準借不充分で正確に知り得たかつたが，次年情においては测定

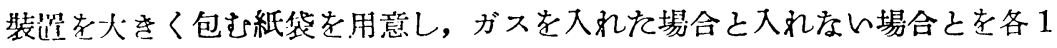
時閉ごつくり返し, 数回にわたり調べてみたが, その程度の計湘では, 天然 ガスそのものの放射能（ガムマ線放射）を認めるに至らをかつた。しかし， 以上では検知されれい位微量にはあるのかもしれず，したがつて長年月に わたる天然ガスの地下からの漏洩が，表土の放射性の不均等に全然関与しな かつたとは，断言することはできないであろら。

\section{6. 結帝}

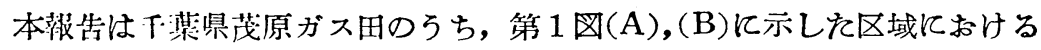
ガムマ線强㹂分们老計测し，第 2 因(A)，(B)に示し，これと潜在断層の推定

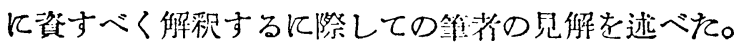

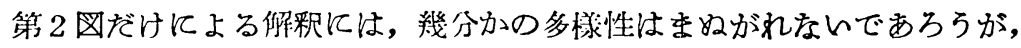

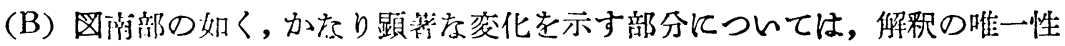
は鼠大寸るものと兄られる。

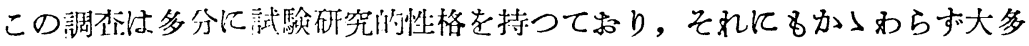

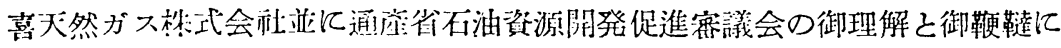

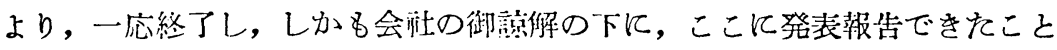
を深く感㴬している。ここに松淍副社压，三川地質部辰证に審議会委員各位 に対し，厚くお礼中上ぐる次第である。おお，調榲中お泾話になつた会社の

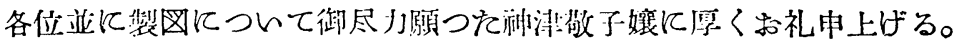

\section{文献}

1) 淵田隆門：ガム、線探鉙法の研究 (1), 東京大学立地自然科学研究所報告, 第6 昂 (昭和25年12月), $6 \sim 12$

静岡県燒津ガス田の天然ガスについては, 地转調查所ラドン計によつて, 明らかに 放射性が認められたと聞いている。 